\title{
PERSEPSI MAHASISWA KEPERAWATAN MENGENAI PEMIMBINGAN KLINIK DI AKPER DHARMA WACANA METRO
}

\section{PERCEPTION OF NURSING STUDENTS ABOUT CLINICAL REFLECTION IN AKPER DHARMA WACANA METRO}

\author{
Apriyanti \\ Akper Dharma Wacana Metro
}

\begin{abstract}
ABSTRAK
Memasuki era Masyarakat Ekonomi Asia (MEA), melahirkan tuntutan akan pelayanan kesehatan yang profesional. Bentuk pelayanan profesional ini diberikan oleh perawat yang memiliki kemampuan, sikap dan kepribadian yang sesuai dengan tuntutan profesi keperawatan. Penelitian ini bertujuan untuk mengetahui persepsi mahasiswa keperawatan mengenai bimbingan klinik di Akper Dharma Wacana Metro. Penelitian ini merupakan jenis penelitian kuantitatif non eksperimental dengan pendekatan cross sectional. Hasil penelitian ini menunjukkan bahwa $67,7 \%$ responden ingin pembimbing meluangkan waktu untuk evaluasi dirinya dengan mahasiswa. Sebanyak $67,7 \%$ responden setuju metode tim dan studi kasus selalu dilakukan dalam bimbingan klinik namun 67,7 \% responden menyatakan metode bed side teaching tidak selalu dipraktikkan. 90,3\% responden menyatakan lahan klinik memiliki keanekaragaman kasus dan pasien serta $33 \%$ responden menyatakan staf keperawatan di lahan praktek klinik kurang mampu memberikan pelayanan keperawatan yang efektif kepada pasien. Dalam proses pembimbingan perlu dilakukan perpaduan metode diantaranya adalah metode bed side teaching, metode observasi, studi kasus dan metode tim. Disamping itu tersedianya fasilitas fisik, pembimbing klinik, keanekaragaman kasus dan jumlah pasien serta manajemen keperawatan yang baik di lahan praktik turut memberikan kontribusi dalam proses pendidikan klinik bagi profesi keperawatan.
\end{abstract}

Kata kunci : persepsi mahasiswa, bimbingan klinik.

\begin{abstract}
Entering the era of Asian Economic Community (MEA), gave birth to the demand for professional health services. This form of professional service is provided by nurses who have the ability, attitude and personality in accordance with the demands of the nursing profession. This study aims to determine the perception of nursing students about clinical guidance in Akper Dharma Wacana Metro. This research is a kind of non experimental quantitative research with cross sectional approach. The results of this study indicate that $67.7 \%$ of respondents want mentors to take the time to self-evaluation with students. As many as $67.7 \%$ of respondents agree the team method and case study is always done in clinical guidance but $67.7 \%$ of respondents said the method of bed side teaching is not always practiced. $90.3 \%$ of respondents stated that clinic land has a diversity of cases and patients and $33 \%$ of respondents said nursing staff in clinical practice areas are less able to provide effective nursing services to patients. In the counseling process needs to be done combination of methods such as bed side teaching method, observation method, case study and team method. Besides, the availability of physical facilities, clinical counselors, case diversity and the number of patients and good nursing management in the field of practice also contributes in the clinical education process for the nursing profession.
\end{abstract}

Keywords: student perception, clinical guidance 


\section{PENDAHULUAN}

Kemajuan ilmu pengetahuan dan teknologi di segala bidang termasuk bidang kesehatan, peningkatan status ekonomi masyarakat, dan peningkatan perhatian terhadap pelaksanaan Hak Asasi Manusia menyebabkan masyarakat semakin sadar akan pentingnya hidup sehat serta melahirkan tuntutan akan pelayanan kesehatan yang professional ${ }^{1}$.

Bentuk pelayanan profesional ini seyogyanya diberikan oleh perawat yang memiliki kemampuan serta sikap dan kepribadian yang sesuai dengan tuntutan profesi keperawatan ${ }^{2}$. Langkah pertama yang perlu ditempuh untuk menghadapi tuntutan akan pelayanan yang profesional adalah penataan pendidikan keperawatan yaitu pengembangan pendidikan keperawatan professional dengan landasan kokoh yang harus berlandaskan pada wawasan keilmuan, orientasi pendidikan serta kerangka konsep pendidikan ${ }^{3}$.

Pengembangan sistem pendidikan tinggi keperawatan sangat penting dan sangat berperan dalam pengembangan pelayanan keperawatan professional ${ }^{2}$. Hal ini sesuai dengan tujuan pendidikan tinggi keperawatan di Indonesia yaitu untuk menghasilkan perawat yang mampu memberikan pelayanan keperawatan profesional untuk pasien.
Sistem pendidikan keperawatan menyediakan proses pembelajaran yang komprehensif dengan menggunakan beberapa bentuk metode pembelajaran di kelas, di laboratorium, dan lahan praktik di klinik $^{4}$. Di lahan praktik klinik peserta didik memerlukan bimbingan dari perawat pendidik yang bertanggung jawab dalam memastikan bahwa siswa dapat belajar bagaimana mengaplikasikan teori atau ilmu yang mereka dapat di bangku kuliah, teknik-teknik dalam praktik, dan berkembang menjadi seorang individu perawat yang dewasa ${ }^{5}$.

Untuk mewujudkan hal tersebut diperlukan pula metode bimbingan yang tepat dan efektif serta lahan praktik klinik yang mendukung sehingga memungkinkan bagi pembimbing dan siswa perawat dapat bersama-sama belajar menjadi perawat professional. Selain perannya sebagai pembimbing klinik, Perawat juga harus memastikan para pasien mendapat pelayanan keperawatan yang berkualitas tinggi ${ }^{6}$. Oleh karena itu diperlukan proses bimbingan klinik yang efektif dan efisien untuk menyeimbangkan hal-hal tersebut diatas.

Pada sebuah penelitian yang dilakukan pada tahun 2003 oleh Nurachmah Elly, dkk dari Fakultas Ilmu Keperawatan Universitas Indonesia, dengan judul "Hubungan antara metode pembelajaran, 
partisipasi pembimbing klinik dan performa peserta didik sebagai mahasiswa S1 keperawatan" hasilnya menunjukkan bahwa variabel yang paling mempengaruhi kinerja klinik, salah satunya adalah partisipasi pembimbing kinik ${ }^{7}$.

Sedangkan penelitian yang dilakukan pada 2006 oleh Susana Widyaningsih dari dengan judul Persepsi Mahasiswa Keperawatan Mengenai Pembimbingan Klinik di Program Studi Ilmu Keperawatan di Semarang hasilnya menunjukkan bahwa hubungan interpersonal antara pembimbing klinik dengan peserta didik yang didalamnya terdapat sifat empati, keterbukaan, keadilan, dan penghargaan dapat meningkatkan efektivitas pembelajaran klinik.

Selama proses bimbingan berlangsung dengan waktu yang telah ditentukan maka akan tercipta interaksi yang cukup intens antara peserta didik dengan pembimbing, perawat ruangan, dan staf kesehatan yang lain di lahan praktik klinik. Pada akhirnya dari peserta didik akan terbentuk suatu persepsi mengenai proses bimbingan yang berlangsung di klinik.

\section{METODE PENELITIAN}

Partisipan yang ikut dalam penelitian ini adalah mahasiswa Akper dharma wacana Metro sejumlah 62 orang. Penelitian dengan desain studi cross sectional telah dilaksanakan pada bulan Maret- Mei 2017 di Akper Dharma Wacana metro.Pada penelitian ini tidak melalui rekomendasi dan uji etik dari komite etik. Analisis data yang dilakukan meliputi analisis univariat karakteristik responden. Analisis bivariat digunakan uji chi-square.

\section{HASIL PENELITIAN}

\section{Karakteristik Responden}

Tabel 1. Distribusi frekuensi jenis kelamin dan umur responden

\begin{tabular}{|c|c|c|c|}
\hline No & Karakteristik & Frekuensi & $(\%)$ \\
\hline & Jenis Kelamin & & \\
\hline 1 & perempuan & 21 & 33,9 \\
\hline \multirow[t]{2}{*}{2} & Laki-Laki & 41 & 66,1 \\
\hline & Umur & & \\
\hline 1 & 19 tahun & 7 & 11,3 \\
\hline 2 & 20 tahun & 26 & 41,9 \\
\hline 3 & 21 tahun & 17 & 27,4 \\
\hline 4 & 22 tahun & 10 & 16,1 \\
\hline 5 & 23 tahun & 2 & 3,2 \\
\hline
\end{tabular}

Tabel 1 menunjukkan bahwa responden dalam penelitian ini sebagian besar terdiri dari laki-laki dengan jumlah 41 orang ( $66,1 \%$ ) dan umur responden 20 tahun memiliki prosentase yang paling besar dengan jumlah 26 responden $(41,9 \%)$. 


\section{Bagian praktik}

Tabel 2 Distribusi frekuensi praktik klinik yang telah dijalani responden

\begin{tabular}{cccc}
\hline No & $\begin{array}{c}\text { Bagian } \\
\text { praktik }\end{array}$ & $\begin{array}{c}\text { Frekuens } \\
\mathrm{i}(\mathrm{n})\end{array}$ & $\begin{array}{c}\text { Prosentas } \\
\mathrm{e}(\%)\end{array}$ \\
\hline 1 & Lab & 62 & 100 \\
& Klinik & & \\
2 & KMB & 62 & 100 \\
3 & KGD & 62 & 100 \\
4 & Materni & 62 & 100 \\
& tas & & 100 \\
5 & Anak & 62 & \\
\hline
\end{tabular}

Tabel 2 menunjukkan bahwa semua responden sudah melalui 4 bagian praktik pada KMB, KGD, Maternitas, Anak.

Berdasarkan hasil penelitian, sebagian besar responden $(66,1 \%)$ adalah laki-laki dan $33,9 \%$ adalah responden perempuan Hal ini di sebabkan sampel yang dipilih penulis adalah mahasiswa Akper Dharma Wacana yang dari semester II berturut turut praktik di RS Ahmad Yani Metro. Saat praktik klinik keperawatan Maternitas, mahasiswa putri sebagian besar melaksanakan praktik di BPS dan sebagian dibagi ke beberapa RS. Sehingga prosentase responden putra lebih banyak daripada yang putri.

Hasil penelitian menunjukkan bahwa semua responden adalah mahasiswa semester IV yang telah mengikuti 5 stase praktik yaitu Lab Klinik, KMB II, KGD, Maternitas, dan Anak dimana pada saat ini lebih banyak praktik di RS Ahmad Yani Metro. Hal ini akan berpengaruh pada proses bimbingan klinik dimana latar belakang akademik mencakup penguasaan materi pelajaran, pengalaman sebelumnya mengenai kasus akan mempengaruhi pemahaman mahasiswa terhadap praktik klinik ${ }^{20}$.

Hal yang sama juga dijelaskan oleh konsep-konsep yang diajukan Thiagarajan bahwa dalam sistem pengajaran perlu memperhatikan latar belakang akademik dan sosial diantaranya adalah tingkat pengetahuan mengenai materi yang akan disajikan, latar belakang pengalaman yang telah dimiliki dan ketrampilan akan peralatan yang digunakan ${ }^{31}$.

Pendidikan tinggi keperawatan sangat berperan dalam membina sikap, pandangan dan kemampuan professional lulusannya. Diharapkan perawat mampu bersikap dan berpandangan profesional, berwawasan keperawatan yang luas serta mempunyai pengetahuan ilmiah keperawatan yang memadai dan menguasai ketrampilan profesional secara baik dan benar ${ }^{3}$. 
Selama pendidikan di lahan klinik, mahasiswa mendapat pembimbingan klinik. Bimbingan klinik merupakan suatu proses pemberian bantuan yang terusmenerus dan sistematis dari pembimbing klinik kepada yang dibimbing agar tercapai kemandirian diri dalam pemahaman, pengarahan diri dan perwujudan diri dalam mencapai tingkat perkembangan yang optimal dan penyesuaian diri dengan lingkungan ${ }^{14}$. Ada 4 unsur yang berkaitan dengan bimbingan klinik yaitu pembimbing klinik, mahasiswa, metode bimbingan dan lahan praktik klinik ${ }^{13}$.

\section{Persepsi mahasiswa keperawatan mengenai hubungan intepersonal antara pembimbing dengan peserta didik}

Sebanyak 42 responden $(67,7 \%)$ menyatakan bahwa pembimbing tidak menggunakan waktu senggang diantara pelajaran untuk melakukan proses reflektif diri atau evaluasi dirinya dengan mahasiswa. Proses reflektif diri merupakan cara "melihat" diri dari perspektif orang lain, pada proses ini antara pembimbing dengan mahasiswa perlu memiliki sikap jujur, keterbukaan dan kemampuan untuk menerima kritik dan saran dari pihak lain. Proses reflektif diri jarang dilakukan oleh pembimbing dengan mahasiswa dapat diakibatkan oleh faktor penghambat diantaranya yaitu kurangnya waktu yang dimiliki, karakter pribadi dari perawat, kondisi fisik dan psikologis yang menurun ${ }^{5}$.

Hasil penelitian ini menunjukkkan ketidaksesuaian dengan pendapat yang dikemukaan oleh Golden (1997) dalam berjudul On Becoming a Trainer, dimana faktor-faktor penting dalam situasi belajar yang memungkinkan terjadinya pertumbuhan dan perkembangan profesionalisme yaitu suasana yang mendorong terjadinya introspeksi, evaluasi diri dan keterbukaan ${ }^{31}$.

Pada kenyataannya walaupun proses reflektif diri bisa dikatakan jarang dilakukan oleh pembimbing klinik namun dalam proses bimbingan, mahasiswa menyatakan pembimbing berempati jika mahasiswa melakukan kesalahan dalam proses pembelajaran, menggunakan kata "tolong dan terimakasih" ketika meminta bantuan kepada mahasiswa.

King \& Gerwig menyatakan bahwa empati merupakan suatu aspek yang sangat penting dalam terbentuknya hubungan interpersonal yang kuat antara pembimbing dengan peserta $\operatorname{didik}^{5}$. Seperti dianjurkan Carl Rogers bahwa empathy adalah "menyetel" pada "gelombang pemancar" para peserta didik, mencoba melihat situasi sebagaimana mereka melihatnya dan bersikap manusiawi. Menurut Rogers sifat empati sangat perlu dimiliki oleh seorang perawat profesional, 
apabila pembimbing mampu memahami peserta didik dari dalam dirinya dan memiliki rasa kepekaan selama proses pembelajaran maka akan meningkatkan lingkungan belajar yang mendukung secara signifikan ${ }^{4}$.

Sifat empati dapat diterapkan dalam hubungannya dengan pasien maupun rekan sejawat terutama dalam hubungannya dengan pasien sangat penting artinya, adanya sifat empati akan membuat pasien merasa dimengerti dan dipahami sehingga pada akhirnya akan tercapai salah satu tujuan dari pelayanan keperawatan profesional yaitu kepuasaan klien ${ }^{3}$.

Sebanyak 43 responden $(69,4 \%)$ menyatakan bahwa pembimbing memberi teguran kepada mahasiswa yang bersikap tidak ramah terhadap klien dan keluarganya maupun kepada staf di bangsal dan hasil penelitian juga menunjukkan 49 responden (79\%) setuju bahwa pembimbing memberi koreksi terhadap kesalahan mahasiswa dengan tegas tanpa menyinggung perasaan. Keadaan ini sesuai dengan teori yang dikutip dari Nursalam mengenai kriteria pembimbing kilnik yang ideal dimana di dalamnya mencakup kemampuan untuk membangun hubungan yang baik antara pendidik sendiri dengan peserta didik, memahami serta memberi koreksi secara terapeutik ${ }^{3}$.
Hasil penelitian dari Depdiknas juga menunjukkan bahwa menciptakan iklim suasana belajar yang kondusif bagi tumbuhnya kreatifitas, cara komunikasi yang baik, menunjukkan sikap menghargai pendapat dan hak orang lain akan meningkatkan efektifitas belajar mahasiswa $^{32}$. Sebuah studi yang dilakukan oleh Aspy \& Roebuck telah membuktikan mengenai kemampuan seorang pengajar dalam hubungan interpersonal akan mempengaruhi proses belajar siswanya. Penelitian ini menemukan bahwa sifat empati, rasa keihlasan dan penghargaan positif atau rasa hormat berhubungan secara signifikan dengan pembelajaran kognitif (cognitif learning) dan cenderung mempertinggi proses pembelajaran demikian pula jika terjadi keadaan yang sebaliknya ${ }^{5}$.

Kesalahan yang dilakukan oleh peserta didik pada saat mencoba perilaku baru, sikap baru dan pengalaman baru merupakan bagian yang wajar dari proses belajar. Karena proses belajar di praktik klinik mengharuskan mahasiswa berani mencoba dan berani bertanggung jawab, sedangkan segala yang baru mengandung resiko terjadinya kesalahan (31). Sebanyak 49 responden (79\%) menyatakan bahwa pembimbing tidak melimpahkan kesalahan kepada mahasiswa yang tidak bersalah.

Sikap pembimbing klinik yang efektif menurut Hildelbrand, Wilson \& Dienst 
disamping mempunyai kompetensi yang memadai di bidang keahliannya, kemampuan dalam membimbing mahasiswa, dan kecakapan dalam menganalisa juga memiliki beberapa karakteristik diantaranya mampu membangun hubungan dan komunikasi yang baik dengan peseta didik dalam proses belajar di klinik ${ }^{4}$.

Sikap seorang pembimbing yang mampu memotivasi dengan menjelaskan kesalahan yang telah dilakukan mahasiswa akan mendorong mahasiswa menjadi lebih kritis, mempunyai bahan perbandingan dalam menilai sikap pembimbing dan berpegang pada norma-norma yang ada dalam lingkungannya ${ }^{31}$.

\section{Persepsi mahasiswa mengenai metode bimbingan}

Hasil penelitian menunjukkan 42 responden $(67,7 \%)$ menyatakan bahwa pembimbimg sering melakukan proses pembimbingan didekat pasien yang menjadi kasus (bed-side teaching) dan hanya 20 responden $(32,3 \%)$ saja yang menyatakan pembimbing sering melakukan proses pembimbingan didekat pasien (bed-side teaching). Hasil penelitian ini menunjukkan metode bed side teaching yang merupakan salah satu metode yang sangat baik dalam mengajarkan dan mendidik mahasiswa untuk menguasai ketrampilan prosedural, menumbuhkan sikap profesional, mempelajari perkembangan biologis atau fisik, melakukan komunikasi melalui pengamatan langsung ternyata jarang dilakukan oleh pembimbing klinik $^{3}$.

Beberapa faktor penghambat yang dapat menghalangi perawat di dalam memberikan metode bimbingan tersebut, diantaranya yaitu kurangnya waktu dan kurangnya motivasi untuk membimbing. Kedua hal itu merupakan halangan utama dan juga penting dalam menentukan keberhasilan upaya pendidikan. Proses bimbingan yang dilakukan perawat terkadang merupakan prioritas yang rendah $^{23}$.

Proses pembimbingan memerlukan perpaduan metode bimbingan sehingga dapat saling melengkapi kekurangan dari salah satu metode. Metode bed side teaching dapat digabungkan dengan metode kasus dan metode bimbingan praktek. Tiap-tiap mahasiswa mendapat satu kasus yang sesuai untuk dikaji, diintervensi dan dievaluasi sehingga lahan praktik klinik harus mampu menyediakan beragam kasus yang dapat dianalisa oleh tiap mahasiswa. Hasil penelitian mendukung hal tersebut dimana 58 responden $(95,3 \%)$ menyatakan pembimbing memberi kesempatan kepada mahasiswa untuk mengintervensi kasus klien dan 56 responden (90,3 \%) menyatakan setuju bahwa mahasiswa 
diberi kesempatan untuk melakukan evaluasi terhadap kasus klien. Dalam metode ini, menurut Hildelbrand, Wilson \& Dienst diperlukan kecakapan pembimbing dalam menganalisa kasus yang diperoleh dari berbagai sumber dan kemauan berdiskusi untuk menilai dari berbagai segi atau pihak $^{4} .56$ responden $(90,3 \%)$ menyatakan bahwa pembimbing tidak memberi kesempatan kepada mahasiswa untuk melakukannya. Seharusnya dalam metode bimbingan kasus di lahan praktik klinik, pembimbing memberi kesempatan bagi mahasiswa untuk menghadapi tantangan lebih besar untuk meningkatkan daya usaha dan kinerja mahasiswa dalam menghadapi kasus-kasus baru. Hal itu akan dapat memacu motivasinya dalam mengatasi masalah atau tantangan dengan lebih baik $^{34}$. Untuk dapat menangani kasus pasien dengan baik, terlebih dahulu perlu pengkajian yang komprehensif, disini pembimbing berperan dalam mengidentifikasi kesiapan diri mahasiswa melalui konferensi pra praktik klinik. Kurangnya kesempatan mahasiswa untuk melakukan pengkajian secara komprehensif dapat dipengaruhi karena mahasiswa melaksanakan rutinitas ruangan, kurang mampu memanfaatkan waktu luang dan tidak melakukan pengkajian secara fokus ${ }^{3}$.
Selanjutnya pada tahap intervensi yang dilakukan oleh mahasiswa terhadap kasus klien, 38 responden $(61,3 \%)$ menyatakan tidak setuju bahwa pembimbing tidak membantu melakukan implementasi yang tidak bisa dilakukan mahasiswa. Metode observasi kasus diterapkan oleh pembimbing klinik dimana sebagai perancang pengalaman dan belajar kreatif dalam metode ini, pembimbing membatasi perannya sesedikit mungkin. Oleh karena itu intervensinya hanya pada saat yang benar-benar perlu dan dirasakan akan membantu kelancaran proses belajar mahasiswa dalam praktik keperawatan ${ }^{31}$. Pembimbing akan menganjurkan mahasiswa untuk belajar mandiri dan bertanggung jawab selama proses belajarnya ${ }^{3}$.

Pada dasarnya, menurut teori belajar Gestalt-Medan, belajar adalah upaya memperoleh insight atau pemahaman. Agar diperoleh pemahaman ini, maka proses belajar harus dilakukan secara aktif dalam arti individu harus turut aktif melakukan kegiatan belajar tersebut (learning by doing). Proses ini dapat juga dilaksanakan dengan menggunakan metode pemecahan masalah (problem solving) untuk mempelajari ilmu keperawatan ${ }^{33}$.

Terkait dengan teori belajar di atas, mayoritas responden yaitu 42 orang $(67,7$ $\%)$ responden menyatakan bahwa 
pembimbing membahas kasus yang dihadapi bersama mahasiswa dan dalam metode bimbingan ini,. Namun sebanyak 36 responden $(58,1 \%)$ menyatakan bahwa pembimbing jarang melakukan diskusi dengan mahasiswa dalam proses bimbingan. Sehingga dapat disimpulkan bahwa pembimbing dalam hal ini hanya membahas kasus mahasiswa secara satu arah namun jarang melakukan diskusi bersama secara dua arah. Dalam bimbingan klinik seharusnya peran pembimbing sebagai sebagai penyebar pengetahuan atau nara sumber. Pembimbing menyediakan sebanyak mungkin bahan yang membahas masalah dari segala segi ${ }^{31}$. Pembimbing memberi penjelasan yang sesuai dengan daya tangkap mahasiswa disertai contoh yang mudah dipahami. Pembimbing yang baik akan mendengarkan dan bertindak sebagai nara sumber (resource) bagi mahasiswa bimbingannya dan mempercayai bahwa mahasiswa mampu menemukan alternatif dan pemecahan masalah yang memuaskan mereka $^{31}$.

Dalam diskusi kasus klien, para peserta berpikir bersama dan mengungkapkan pikirannya sehingga menimbulkan pengertian pada diri sendiri, pada pandangan teman kelompoknya, dan juga pemahaman pada masalah yang didiskusikan $^{34}$. Setelah tercapainya pemahaman terhadap masalah yang dihadapi maka prinsip-prinsip bimbingan di lapangan praktik menyatakan bahwa pentingnya memberi kesempatan pada peserta didik untuk menerapkan ilmu pengetahuan secara terintegrasi dalam situasi nyata ${ }^{16}$.

Berdasarkan pada salah satu prinsip bimbingan praktik maka sebanyak 56 responden dengan prosentase 90,3\% menyatakan tidak setuju bahwa pembimbing tidak memberi kesempatan kepada mahasiswa untuk berinteraksi dengan staff yang ada di bangsal. Hasil ini akan sejalan dengan pernyataan dari responden selanjutnya yaitu sebanyak 56 orang $(90,3 \%)$ menyatakan setuju bahwa mahasiswa diberi kesempatan untuk bekerjasama dengan tim kesehatan lain. Dari metode pelayanan keperawatan yang dilakukan secara tim, mahasiswa akan mempelajari mengenai kerjasama yang baik yang akan meningkatkan hubungan profesional antara perawatan dan tim kesehatan lainnya seperti ahli gizi, dokter, apoteker dan lain-lain ${ }^{3}$.

Menurut Marquis dan Huston metode keperawatan tim yang menggunakan anggota dari disiplin ilmu kesehatan yang berbeda-beda dalam memberikan asuhan keperawatan kepada sekelompok pasien, termasuk dalam jenis model pemberian asuhan keperawatan profesional (MAKP) ${ }^{3}$. Metode ini memungkinkan pelayanan keperawatan yang menyeluruh, mahasiswa 
juga akan mempelajari cara menangani banyak sifat-sifat diantara para staf termasuk masalah prasangka, berkurangnya perhatian, penilaian superfisial dan berkurangnya pengertian serta semua masalah lain yang akan mereka hadapi yang membuka jalan untuk berkembang lebih dewasa ${ }^{35}$.

Metode bimbingan praktik yang diterapkan dalam proses bimbingan klinik harus memiliki kriteria yang sesuai dengan tujuan pengalaman praktek klinik, kemampuan, pengalaman, dan karakteristik peserta didik, kemampuan pembimbing, serta sumber-sumber dan keterbatasan lahan praktek ${ }^{4}$

\section{Persepsi mahasiswa mengenai lahan praktik klinik}

Sebanyak 56 responden $(90,3 \%)$ menyatakan bahwa lahan praktek klinik mempunyai beragam kasus yang dapat dianalisa oleh mahasiswa, baik metode kasus, bed side teaching maupun metode bimbingan praktek klinik memerlukan beragam kasus yang sesuai untuk tiap mahasiswa yang dapat memberi kesempatan kepada mahasiswa untuk menerapkan ketrampilan prosedural dan interpersonal. Menurut Dorothy Reilly salah satu kriteria lahan praktik yang ideal adalah mempunyai beragam kasus dan pasien dalam jumlah yang memadai ${ }^{4}$.
Oleh karena itu dengan adanya beragam kasus dan pasien di lahan praktik klinik, sejumlah 43 responden $(69,4 \%)$ menyatakan kondisi lahan praktik memungkinkan mahasiswa

mengaplikasikan semua pengetahuan dan ketrampilan keperawatannya. Karena dalam praktik klinik seharusnya menyediakan pengalaman dengan pasien dan segala masalahnya dimana hal tersebut memungkinkan peserta didik untuk menggunakan pengetahuannnya dalam asuhan keperawatan, mengembangkan ketrampilan mengatasi masalah (problem solving) dan membuat keputusan serta bertanggung jawab atas segala tindakannya. Berdasarkan teori dari Argyris, sebuah teori ketrampilan belum dapat dipelajari dengan baik sebelum teori tersebut dipraktikkan ${ }^{4}$.

Sejumlah 41 orang responden $(6,1 \%)$ menyatakan setuju bahwa terdapat pembimbing klinik (Clinical Instructure) dari lahan praktek klinik di tiap bangsal. Disamping menyediakan beragam kasus yang dapat dianalisa oleh mahasiswa, keberadaan pembimbing klinik yang merupakan pakar di bidangnya sangat penting sehingga dapat berfungsi sebagai nara sumber (resource) maupun fasilitator dalam proses bimbingan. Kemampuan pembimbing ini didukung dengan pernyataan dari 56 orang responden $(90,3$ $\%)$ menyatakan bahwa staf keperawatan di 
lahan praktik klinik merupakan tenaga yang mampu menjadi fasilitator dalam mencapai tujuan belajar.

Sebanyak 33 responden $(53,2 \%)$ menyatakan bahwa staf keperawatan di lahan praktek klinik merupakan tenaga yang kurang mampu memberikan pelayanan yang efektif kepada pasien. Hal ini dapat dipengaruhi jumlah perawat yang tidak seimbang dengan jumlah pasien di bangsal sehingga perawat tidak memiliki waktu lebih untuk melakukan tindakan keperawatan yang efektif. Menurut teori yang dikemukakan oleh Lipetz, keterbatasan tenaga perawat di ruangan merupakan salah satu faktor penghambat proses bimbingan yang menyebabkan perawat kekurangan waktu untuk membimbing sehingga dapat dikaitkan dengan jarang dilakukan metode bimbingan bed side teaching di lahan praktik $^{5}$. Pernyataan responden diatas bertolak belakang dengan pernyataan sebanyak 45 responden $(72,6 \%)$ menyatakan bahwa lahan praktek klinik tidak menggunakan mahasiswa untuk memenuhi kekurangan tenaga perawat di ruangan.

Pengajar klinik yang efektif juga berperan sebagai perawat pelaksana (clinician). Mempertahankan kompetensi klinik sangat penting, diantaranya untuk dapat mengembangkan pengetahuan dan ketrampilan peserta didik. Oleh karena itu hasil penelitian tersebut membuktikan bahwa lahan praktik klinik telah memenuhi salah satu karakteristik sebagai lahan praktik perlu ditingkatkan untuk proses pembimbingan mahasiswa keperawatan yaitu terdapat staf keperawatan yang merupakan tenaga terpilih dan mampu memberikan pelayanan yang efektif kepada pasien serta berfungsi sebagai fasilitator dalam mencapai tujuan belajar mahasiswa keperawatan ${ }^{20}$.

Menurut kriteria lahan praktik yang ideal, faktor penghambat yang lain kemungkinan adalah pengaturan staff yang kurang effisien sehingga mahasiswa dibebani dengan tanggungjawab sebagai staff di ruangan. Hal tersebut berpengaruh dalam proses pembimbingan terutama pada peserta didik yaitu stress atau tekanan yang terus-menerus dan kurangnya waktu belajar. Menurut teori pembelajaran kognitif yang dikemukakan oleh Hill dan Reese agar terjadi transfer pengetahuan maka peserta didik harus belajar dengan cara dan kondisi tertentu ${ }^{5}$

Lahan praktik klinik adalah unsur yang sangat penting dalam proses bimbingan klinik. Lahan praktik perlu diseleksi agar memungkinkan pencapaian tujuan belajar bagi mahasiswa, yang perlu dipertimbangkan pada lahan praktik adalah mempunyai pasien yang cukup, dalam jumlah maupun jenis penyakit untuk 
memberi pengalaman belajar mahasiswa, mempunyai fasilitas fisik, pengadaan dan alat-alat yang cukup dan sesuai dengan kebutuhan belajar, terdapat penanggung jawab dan staf pengajar di lahan praktek dan mempunyai manajemen pelayanan keperawatan yang baik ${ }^{23}$.

\section{SIMPULAN}

Hubungan interpersonal antara pembimbing klinik dan peserta didik keperawatan merupakan suatu aspek penting yang sangat menunjang peningkatan efektivitas pembelajaran di klinik. Kualitas pembimbingan klinik ditentukan oleh pembimbing klinik dan mahasiswa, metode bimbingan yang diterapkan serta kondisi lahan klinik.

\section{DAFTAR PUSTAKA}

1. Gaffar J. (1999). Pengantar keperawatan profesional. Jakarta: Penerbit Buku Kedokteran EGC.

2. Marr,H \& Giebing, H. (2001). Penjaminan kualitas dalam keperawatan: konsep metode dan studi kasus. Jakarta: Penerbit Buku Kedokteran EGC.

3. Nursalam. (2002). Manajemen Keperawatan: aplikasi dalam praktik keperawatan professional. Jakarta: Salemba Medika.

4. Oermann R. (1985). The clinical field, it is using in nursing education. Connectiont: Appleton - Century - Crofts.

5. Bastable, S.B. (2002). Perawat sebagai pendidik, prinsip - prinsip pengajaran dan pembelajaran. Jakarta: Penerbit Buku Kedokteran EGC.

6. Tang $\mathrm{F}$, Chou S, Chiang $\mathrm{H}$. Student's perception of effective dan ineffective clinical instructors. Journal of nursing education. Vol 44.

7. Nurachmah, Elly. dkk. The relationship between learning methods, participatio of nurse educatior, and the student's clinical performance as perceived by $\mathrm{S} 1$ nursing education. E:/JURNAL PENELITIAN/Fakultas Ilmu Keperawatan Universitas Indonesia. htm.

8. Kozier E \& Oliveri. (1991). Fundamental of nursing: concepts, process and practice. Four Edition. California: Addison Wesley..

9. Rahmat, J. (1986). Psikologi komunikasi. Bandung: Rendja RK Karya.

10. Atkinson, R.L. () Pengantar psikologi. Jilid I, Edisi II. Alih Bahasa: Dr. Widjaya Kusuma. Batam: Interaksa

11. Taylor, L \& La Mone. (1997). Fundamental of nursing: the art 
and science of nursing care. $B$. Third Edition. Philadelphia: Lippincott.

12. Notoadmodjo, S. (2003). Ilmu kesehatan masyarakat: prinsip prinsip dasar. Jakarta: PT. Rinea Cipta.

13. Arikunto. (1995). Prosedur penelitian, suatu pendekatan praktek. Edisi Revisi V. Jakarta: Pamatorn Pressindo.

14. Thantowi. (1995). Manajemen bimbingan dan konseling. Jakarta: Pamatorn Pressindo.

15. Abroza, A. (2004). Bimbingan dan konseling. Semarang: Program Studi Psikologi Fakultas Kedokteran UNDIP.

16. Aziz, A.H. (2002). Pengantar pendidikan keperawatan. Jakarta: CV Agung Seto.

17. (2000). Clinical Training skills. Jakarta: Choachity Skills.

18. Hidebrand, W.D. (1971). Evaluating university teaching. Berkeley, California: Center for Rersearch and Development in Higher Education.

19. Purwanto, N. (2002). Pskiologi pendidikan. Bandung: PT. Remaja Rosdakarya.
20. Hamalik, O. (2003). Perencanaan pengajaran berdasarkan pendekatan sistem. Jakarta: Bumi Aksara.

21. Depertemen Kesehatan RI. ( ). Pedoman pengajaran klinik bagi isntruktur klinik PBB. Jakarta: Pusdiknakes.

22. Sudarsono R.S. (1999). Semiloka bimbingan klinik pada mata ajar keperawatan medikal bedah. Jakarta: FIK UI.

23. Pujiastuti, S. E. (1998). Hasil pelatihan pembelajaran klinik bagi mahasiswa akademi keperawatan di Indonesia. Jakarta: Pusat Pendidikan Tenaga Kesehatan Departemen Kesehatan RI. 